\title{
Carbon Emission Disclosure, Good Corporate Governance, Financial Performance, and Firm Value
}

\author{
Pipin KURNIA ${ }^{1}$, Edfan DARLIS ${ }^{2}$, Adhitya Agri PUTRA ${ }^{3}$
}

Received: September 01, 2020 Revised: October 26, 2020 Accepted: November 05, 2020

\begin{abstract}
This research aims to examine (1) the effect of carbon emission disclosure on firm value, (2) the effect of good corporate governance on firm value, (3) the mediating role of financial performance between carbon emission disclosure and firm value, and (4) the mediating role of financial performance between good corporate governance and firm value. The research sample includes 43 mining, agro, and manufacturing firms listed in the Indonesian Stock Exchange over the 2015-2017 period. Carbon emission disclosure is measured by an indicator of the Global Reporting Initiative Series of Environmental Aspect. Good corporate governance is measured by the corporate governance score of shareholder rights, boards of directors, outside directors, audit committee and internal auditor, and disclosure to investors. Financial performance is measured by return on assets, while firm value is measured by Tobin's Q. Data analysis uses the structural equation modeling. The result shows carbon emission disclosure and good corporate governance have no direct effect on firm value. On the other hand, financial performance mediates the effect of carbon emission disclosure and good corporate governance on firm value. It shows that higher carbon emission disclosure and good corporate governance are meaningless for the investor if they do not give any financial performance improvement.
\end{abstract}

Keywords: Carbon Emission Disclosure, Good Corporate Governance, Financial Performance, Firm Value

JEL Classification Code: G30, O16, Q51, Q56

\section{Introduction}

The ecology crisis happens when there is profit maximization with extreme effort, included in ethical and unethical ways, such as environmental harms (Khan et al., 2020; Lako, 2018). Investors consider profit as not the only investment evaluation, but also environmental issues. Business paradigm shifts from a single bottom-line (profit) into a triple bottom-line (profit, people, and the

${ }^{1}$ First Author and Corresponding Author. Lecturer, Department of Accounting, Faculty of Economics and Business, University of Riau, Indonesia [Postal Address: Kampus Bina Widya KM. 12.5, Simpang Baru, Kec. Tampan, Kota Pekanbaru, Riau 28293, Indonesia]

Email: pipinkurnia.ur@gmail.com

${ }^{2}$ Lecturer, Department of Accounting, Faculty of Economics and Business, University of Riau, Indonesia.

Email: edfandarlis.ur@gmail.com

${ }^{3}$ Lecturer, Department of Accounting, Faculty of Economics and Business, University of Riau, Indonesia. Email: adhitrebe@gmail.com

(c) Copyright: The Author(s)

This is an Open Access article distributed under the terms of the Creative Commons Attribution Non-Commercial License (https://creativecommons.org/licenses/by-nc/4.0/) which permits unrestricted non-commercial use, distribution, and reproduction in any medium, provided the original work is properly cited. planet) where firms' contribution to the environment is also important (Wiranata, 2014). Investor evaluation is important to determine firm value. Since firm value reflects the stock price, investor evaluation of firm reputation can also affect the firm stock price.

Firm reputation can be built by improving the concern and commitment to environmental issues, such as social and environmental responsibility (Machmuddah et al., 2020; Somjai et al., 2020). It helps firms to not depend on financial benefits only, but also can keep business sustainability (Nguyen et al., 2020; Ongsakul \& Sen, 2019). High firm value proves that investors trust the firm to achieve, not only good financial performance, but also a good business prospect in the future (Kelvin et al., 2017). The firm needs to disclose environmental information to make a good image for stakeholders. It, later, develops a reputation and motivates investors to give their funding resources. Epstein and Freedman (1994) find that investors have an interest in social information on product safety and quality as well as environmental activities in the annual report. Green business can give a significant effect on stock prices (Lako, 2018). Radhouane et al. (2018) find that environment environmental disclosure has a positive effect on firm value. 
One of environmental information is the management of carbon emission. Total carbon emission increased twice since 1970 and has kept growing since 2000 where it comes from 70 percent of fossil fuel, cement, and other processes (Levin \& Fransen, 2017). Carbon dioxide is the major gas of carbon emission and keeps increase (Levin \& Fransen, 2017).

Indonesia is one of the countries that sign the Paris Agreement and elaborated in Act No. 162016 (UU Nomor 16 Tahun 2016). It is a commitment to reduce 29 percent of carbon emission by self-effort and 41 percent of carbon emission by the international partnership of forestry, energy, and industry. All firms should give contributions and support to the government's move of carbon emission reduction. Firms can reduce their carbon emission by managing business emission with carbon accounting. The concept of carbon accounting is a part of environmental accounting that provides information on carbon calculation from the industry process, determinant of carbon reduction target, reporting system, and program development of carbon reduction. It is known well as carbon emission disclosure. Carbon emission disclosure includes carbon emission intensity, energy consumption, corporate governance, the strategy of climate change, carbon emission reduction performance, and risk and opportunity of climate change (Kelvin et al., 2017). Since carbon accounting implementation is costly and can decreases profit, not all firms agree to implement carbon accounting, further, carbon emission disclosure is still voluntary disclosure. On the other hand, Australia provides a specific committee of carbon emission reduction to obligate firms to reduce carbon emission.

Carbon emission disclosure is a value-added for the investor. When firms harm the environment to achieve high profit, they can still maintain high performance if they can reduce pollution (Saka \& Oshika, 2014). An efficient and proactive strategy of environment maintenance can increase firm value. Concrete environmental activities and disclosure can give a positive effect on firm value (Saka \& Oshika, 2014). Anggraeni (2015) finds that carbon emission disclosure improves firm value. Hapsoro and Ambarwati (2018) also find that carbon emission disclosure has an effect on stock trading volume. Investor gives positive responses to voluntary carbon emission disclosure because they believe that carbon emission information is an important consideration to determine business sustainability (Anggraeni, 2015). Carbon emission disclosure can also increase financial performance. As a business ethic implementation, carbon emission disclosure improves the social trust of stakeholders, especially customers to use environmentally friendly products. It improves firms' revenue, further, increase firms' profitability (Kelvin et al., 2017). Higher profitability leads to higher firm value.
Firm value is also determined by good corporate governance. Good corporate governance is a concept based on agency theory where it is expected to give trust for investors. Good corporate governance relates to how to make investors trust firm managers that they can get positive returns and managers have interest aligned with the investor (Prasinta, 2012). Good corporate governance leads to a low possibility of managers to fulfill their interest. Good corporate governance can be seen by corporate governance score where a higher score leads managers to act similarly with investor interest. Assurance of investors' rights gives a higher value for the firm. Investor trust can be reduced if good corporate governance is not implemented, such as low transparency of business management. Since good corporate governance is not implemented well, the investor is less likely to invest their money into the firm, further, it reduces firm value. Gwenda and Juniarti (2013), Rizki and Jasmine (2018), and Santoso (2017) find that good corporate governance has an effect on firm value. Further, Santoso (2017) finds that good corporate governance increase firm value through financial performance.

\section{Literature Review}

\subsection{Legitimacy Theory}

Legitimacy theory is a common theory to explain social and environmental disclosure (Deegan et al., 2002; Deegan \& Gordon, 1996; O’Donovan, 2002; Patten, 1992). Legitimacy theory relates to the social contract between the firm and local society (Deegan et al., 2002; Mathews, 1993; Patten, 1991). The fundamental argument of legitimacy theory is that an organization can be survived if it is operated in the scope of society norms (Gray et al., 1996). To maintain the legitimacy in the society, firm voluntarily discloses their social and environmental information to legitimate their business operation and give a good perception of social responsibility (Deegan et al., 2002; O'Donovan, 2002; Patten, 1991). Some studies (e.g., Deegan et al., 2002; Deegan \& Gordon, 1996; Gray et al., 1996) use legitimacy theory to explain social and environmental disclosure.

Firm legitimacy will be threatened if there is a gap between the firm and society. An organization takes a step to cover the "hole" up in the gap between the firm and society's value. The firm has to be a part of society to get their positive perception. Hopefully, good legitimacy can reduce the friction between the firm and society (Deegan et al., 2002). Lindblom (2010) explains that there are four strategies to face legitimacy threats. First, the firm gives relevant information about the change of organization performance to the stakeholders. Second, the firm changes the stakeholders' perceptions of organizational performance. Third, the firm changes the perception by distracting stakeholders' 
concerns into the current issue. Fourth, the firm tries to changes external expectations about their performance. These four strategies play important role in legitimacy maintenance. Positive perception and expectation can be built by voluntary disclosure of social and environmental information (Magness, 2006). Less disclosure can be seen as low responsibility of the firm.

\subsection{Stakeholder Theory}

Stakeholder theory explains that a firm has to be responsible to all stakeholders, not just only shareholders (Barsky et al., 1999). As an important issue of climate change in the society, stakeholders have hope and interest in it. Society pushes (directly and indirectly) firms to disclose environmental information. Information disclosure can be a communication medium between firm and stakeholders since firm management knows more about business operations than other stakeholders. Since investor keeps evaluate related information, firms are motivated to disclose information voluntarily to get high-quality resource access (Meek et al., 1995). Voluntary gas emission disclosure reduces information asymmetry and agency costs. Stakeholder and legitimacy theories are complemented one another.

\subsection{Green Accounting}

Green accounting is a new paradigm in accounting that suggests the accounting process focuses, not only on the financial aspect, but also social and environmental aspects (Lako, 2018). Green accounting refers to three pillars of business which are environment, social, and financial (Elkington, 1997, 2001). It will be a reference for management and financial statement users to make economics and non-economics decisions. Green accounting is a process to identifies, measure, recognizes and discloses expenses of environmental responsibilities (Lako, 2018). Green accounting aims to provide information about the financial position and business performance, corporate risk, business growth prospect and profit, and sustainability for management, shareholders, creditors, customer, employees, and government (Lako, 2018). It is used to make final economics and non-economics decisions. Stakeholders can fully know the information about management quality in business activities that consider the social and environmental aspects as the main condition to achieve sustainability and long-term profitability.

Currently, the financial statement does not provide enough social and environmental information and more focus on financial accounting. The accounting system does not give more space on information about the interaction between firm, society, natural environment, and business consequences on external society and environment.
Social and environmental information can give value relevance to financial information, such as sustainability information (Lako, 2018). Green accounting implementation includes environmentally-friendly material use, good waste management, and corporate social responsibility (Zulhaimi, 2015). Green accounting generates a transparent, comprehensive, accountable, and relevant report as well as develops a positive reputation. It can support customers to buy environmentally-friendly products and build a competitive advantage for the firm.

\subsection{Signaling Theory}

Signaling theory is developed to solve the information asymmetry problem. Since information is important in decision making, the firm needs to give a signal of information to the external parties (Ulum, 2017). Complete, relevant, accurate, and timely information is needed by the investor as an analysis tool for an investment decision. Published information will give a signal for the investor to make a decision. If the information content has positive value then the market participant is expected to analyze the information as the good news.

The annual report is as information disclosure medium and has a function as a monitoring tool on the firms' performance. The annual report includes mandatory disclosure required by the regulation and voluntary disclosure (Wardani, 2011). Based on signaling theory, voluntary disclosure of non-financial information, such as private information, is expected to give a signal as the good news for investors and increase firm value (Arisanti \& Daljono, 2014). Signaling theory also explains that high-quality firms are more likely to give a signal of their competitive advantage to the market. On the other hand, low-quality firms are more likely to disclose mandatory information only. Firms have the motivation to disclose private information voluntarily as it can be interpreted as a positive signal of good performance and reduction of information asymmetry. It leads to a good reputation and can reach a potential investor. The environmental performance gives a signal of substantial future return prospects since it reflects the sustainable business.

\subsection{Hypotheses}

The firm condition implies the strategy formulation. Generally, firms have priority more in economic performance than environmental responsibility (Irwhantoko \& Basuki, 2016). Some researches (e.g., Anggraeni, 2015; Luo \& Tang, 2016; Matsumura et al., 2014; Okpala \& Iredele, 2019; Qiu et al., 2016) find that carbon emission disclosure has a positive effect on firm value. Environmental responsibility is one of the ways to improve a firm competitive advantage and 
investor trust (Okpala \& Iredele, 2019). Carbon emission disclosure can increase firm value because investor more focuses on global environmental issues in the future (Luo \& Tang, 2016). The investor has more interest in the firm with high responsibility for environmental issues since climate change has become an important global issue (Anggraeni, 2015). On the other hand, climate change can be bad news for the market so the investor can give a negative response to environmental disclosure (Anggraeni, 2015). It, indirectly, tells that good business operations can harm the environment. Further, it leads to a bad reputation, sales reduction, and lower stock price. Anggraeni (2015) also explains that the value of assets and cash flow can be lower by carbon emission reduction expenses.

\section{H1: Carbon emission disclosure has an effect on firm} value

Agency conflict comes from interest conflict between the principal (shareholders) and agent (management). It shows that management does not always act as shareholders' interest. A good corporate governance mechanism is expected to solve the agency conflict. Good corporate governance guides the management to run the firm as shareholders' interest. Good corporate governance provides control and monitoring function on the interest alignment between management and shareholders. Good corporate governance reduces the opportunist behavior of management. It allows management to assure the shareholders' rights. Shareholders' rights assurance will increase the firm value. Gwenda and Juniarti (2013), Rizki and Jasmine (2018), and Santoso (2017) find that good corporate governance has an effect on firm value. On the other hand, Siahaan (2014) and Mutmainah (2015) find that there is no relationship between good corporate governance and firm value. It might be corporate governance is as a formality to fulfill the regulation.

H2: Good corporate governance has an effect on firm value

Carbon emission disclosure is a part of corporate social responsibility. It captures the ethical value of the firm. Since investors have a concern about environmental issues, such as global warming, firms are more likely to disclose wider carbon emission information. It is expected to be a signal of a higher reputation. Firms with high profitability are expected to give contribution to carbon emission reduction and disclose it in the annual report or sustainability report. Higher carbon emission disclosure leads to a good reputation and higher revenue with environmentally friendly products. Higher financial performance from carbon emission disclosure implementation will increase firm value. Carbon emission disclosure can increase the firm value if there is also financial performance improvement. Higher carbon emission disclosure without financial performance improvement will give no benefits to the firm value since investor interest also is on the profit when they make an investment decision. Ardiyanto and Haryanto (2017) find that return on equity mediates the effect of corporate social responsibility on firm value. On the other hand, Kelvin et al. (2017) do not find a mediation role in financial performance on the relationship between carbon emission disclosure and firm value.

H3: Financial performance mediates the effect of carbon emission disclosure on firm value

Good corporate governance is a mechanism to protect the investor from shareholder-management interest conflict. Good corporate governance is an agency theory-based concept where it assures investors to get their investment returns. Good corporate governance ensures that management can give the investment return to the investor by preventing management to act opportunist and fraud behavior (Prasinta, 2012). Firms can give return to the investor if the firms can achieve higher financial performance. Higher performance is a signal that firms have good prospects in the future. Higher financial performance is good news for investors and can increase firm value. Santoso (2017) finds that good corporate governance has an effect on firm value through financial performance.

H4: Financial performance mediates the effect of good corporate governance on firm value

\section{Research Method}

\subsection{Sample}

Sample selection uses a purposive sampling method where research samples are limited to some criteria. The criteria include (1) samples are mining, agro, and manufacturing firms listed in Indonesian Stock Exchange 2015-2017, (2) sample publishes an annual report and/or sustainability report, and (3) sample discloses information of carbon emission (at least one policy or item that is related to carbon emission). Net samples are 43 firms as is Table 1.

\subsection{Data and Variables}

Research data is secondary data. The data source is the annual report and sustainability report period 20152017. Data is accessed on www.idx.co.id and each firm website. The data is used to measure the dependent variable, independent variables, and the mediating variable. 
Table 1: Sample

\begin{tabular}{|l|c|}
\hline Criteria & Firms \\
\hline $\begin{array}{l}\text { Mining, agro, and manufacturing firms listed in } \\
\text { Indonesian Stock Exchange 2015-2017 }\end{array}$ & 215 \\
\hline Have no annual report & $(29)$ \\
\hline Foreign currency & $(52)$ \\
\hline Have no carbon emission disclosure & $(82)$ \\
\hline Incomplete data & $(9)$ \\
\hline Net Sample & 43 \\
\hline
\end{tabular}

The dependent variable is the firm value. Firm value reflects the market value of the security. Higher firm value captures higher shareholders' wealth. For listed firms, the stock price is an indicator of firm value. In this research, firm value is measured by Tobin's Q in equation (1) (Wiranata, 2014).

$$
\begin{aligned}
\text { Tobin's } Q= & \text { (Market Value of Equity }+ \text { Book Value } \\
& \text { of Debt }) / \text { Total Assets }
\end{aligned}
$$

The market value of equity is calculated from closing stock price multiplied by the number of outstanding shares. The book value of debt is calculated from the total of working capital, the book value of inventory, and longterm debt.

Independent variables are carbon emission disclosure and good corporate governance. Carbon emission disclosure is measured by the content analysis method where it identifies document and text and quantifies the content based on a specific index. It uses indicator of Global Reporting Initiative (GRI) 305 as a part of series 300 (environmental aspects). The indicator of carbon emission consists of six categories which are: (1) Disclosure of Management (Series of 103), (2) Series of 305-1, (3) Series of 305-2, (4) Series of 305-3, (5) Series of 305-4 (Carbon Emission Intensity), and (6) Series of 305-5 (Carbon Emission Reduction). In six categories of carbon emission disclosure, there are 19 items of reporting disclosure which are: (1) narrative explanation if organization follow the emission regulation in national, regional, or industry scopes and provide the example regulation and related expenses (such as expenses for filter and materials), and emission certification, (2) directly, indirectly, and other indirectly carbon emission in metric ton that similar to $\mathrm{CO} 2$, (3) calculated emission carbon is $\mathrm{CO} 2$, (4) if any, indirectly gross carbon emission energy based on market in metric ton similar to $\mathrm{CO} 2$, (5) biogenic emission $\mathrm{CO} 2$ in metric ton similar to $\mathrm{CO} 2$, (6) activities and categories of other indirectly carbon emission in the calculation, (7) base year of calculation, if any, includes: reason of year selection, emission in base year, context of significant in emission that leads to recalculation of base year emission, (8) emission and potential value of global warming factor source, (9) consolidation approach for emission (equity portion, financial control, or operational control), (10) standard, methodology, assumption, and/or calculation tool, (11) intensity ratio of carbon emission for organization, (12) specific metric of organization for ratio calculation, (13) carbon emission type for ratio intensity calculation (direct, indirect, and other indirect emission), (14) calculated ratio is $\mathrm{CO} 2,(15)$ carbon emission reduction from direct initiative in metric ton similar to $\mathrm{CO} 2$, (16) emission reduction is $\mathrm{CO} 2$, (17) base year or condition, and the reason to choose it, (18) emission reduction scope (direct, indirect, other indirect), and (19) standard, methodology, assumption, and/or calculation tool. Carbon emission disclosure calculation steps are as follows: (a) scoring each item of disclosure with dichotomy scale, (b) since score 1 for the disclosed item, the maximum score will be 19 and the minimum score will be 0 , and (c) calculate the total score for each firm.

Good corporate governance is defined as a system, process, and set of rules in the relationship between stakeholders. Good corporate governance implementation is measured by good corporate governance score that is calculated by five indexes of good corporate governance sub-index: (1) Shareholder Rights (sub-index A), (2) Boards of Directors (sub-index B), (3) Outside Directors (sub-index C), (4) Audit Committee and Internal Auditor (sub-index D), and (5) Disclosure to Investors (sub-index E). Sub-index A consists of: (A1) firm use cumulative vote to choose a board of directors. Cumulative vote refers to the standard rule of commercial code, but the firm can drop it out with majority vote of shareholders, (A2) firm allow voting by email, (A3) firm chooses meeting date with shareholders to avoid the same date with other firms in the same industry, or chooses meeting location, (A4) firm discloses the candidate of director to shareholders in the meeting, and (A5) Board approval to make a transaction with a related party. Sub-index B consists of: (B1) directors are in the meeting at least 75 percent of all meetings (on average), (B2) director position on the meeting agenda of the noted board in the meeting notes, (B3) chief of executive and chief of the commissioner is a different person, (B4) there is an evaluation system in the board of directors, (B5) there is a rule to set the meeting of director, at least it will be disclosed if there is or there is not, and (B6) firm presents four or more meetings of directors in a year. Subindex $\mathrm{C}$ consists of: (C1) firm has at least 30 percent of the independent commissioner, (C2) firm has more than 30 percent of the independent commissioner, (C3) firm has one or more foreign independent commissioner, $(\mathrm{C} 4)$ firm has a board of commissioner nomination committee, 
(C5) independent commissioner does not receive pension fund, (C6) Independent commissioner is allowed to get the advice of external expertise, (C7) firm has independent commissioner evaluation system or a plan to has one, (C8) shareholders approve the aggregate payment for independent commissioner in the shareholder meeting, (C9) independent commissioner is presented at least 75 percent of all meetings, (C10) firm has ethic code for independent commissioner, (C11) firm provides the Contact Person for independent commissioner, (C12) there is a special meeting for the board of commissioner, and (C13) firm does not allow the independent commissioner to buy the firm share. Sub-index D consists of: (D1) there is an independent commissioner in the audit committee, (D2) independent commissioner ratio in the audit committee at least 2/3, (D3) there is a regulation for audit committee or internal audit, (D4) audit committee has a member with accounting skill, (D5) audit committee or audit internal recommends external auditor in the shareholder meeting, (D6) audit committee or audit internal approves the internal audit head appointment, (D7) meeting note records the audit committee or audit internal meeting, (D8) there is an activities report of the audit committee or audit internal, (D9) member of the audit committee is presented at least 75 percent of all meetings, (D10) audit committee or audit internal meets the external auditor to review the financial report, and (D11) audit committee has two or more meetings in a year. Sub-index E consists of: (E1) firm presents the investor relations, especially in the 2015-2017, and (E2) firm website includes information of board member resume. Good corporate governance score is in the equation (2).

$$
\begin{aligned}
& \text { Score of Good Corporate Governance }=\text { Total }_{\text {sub-index A }}+ \\
& \left(\text { Total }_{\text {sub-index B }}+\text { Total }_{\text {sub-index } C}\right) / 2+\text { Total }_{\text {sub-index D }} \\
& + \text { Total }_{\text {sub-index E }}
\end{aligned}
$$

The mediating variable is financial performance. It is defined as profitability. Profitability is measured by Return on Equity (ROE). ROE is a profitability ratio for an investor to evaluate the firm ability to achieve a net income that relates to the dividend payment. ROE is an indicator of how good a firm is to use investor funds in generating income (Istikhoroh \& Suhardiyah, 2016). ROE is calculated from net income divided by total equity.

\subsection{Analysis Method}

The analysis method uses Structural Equation Modeling (SEM) with Warp PLS 10 program. SEM analysis includes descriptive statistics, outer model, inner model, and path analysis.

\section{Results and Discussion}

\subsection{Descriptive Statistics}

Table 2 shows that the average carbon emission disclosure for the research sample is 0.231742 with its deviation of 0.24239822 . The average good corporate governance score for the research sample is 19.18992 with its deviation of 3.2651054. The average financial performance (ROE) for the research sample is 0.119642 with its deviation of 0.27417872 . The average firm value (Tobin's Q) for the research sample is 2.028029 with its deviation of 2.69546891 .

\subsection{Outer Model Analysis}

The outer model analysis includes validity and reliability analysis. Table 3 shows that the loading factor for all variables is above 0.5 . It indicates that the variable is valid. Composite reliability and Cronbach's alpha are above 0.70 . It indicates that the variable is reliable.

\subsection{Inner Model Analysis}

The inner model analysis includes model fit, path coefficient, and $\mathrm{R}^{2}$. Model fit analysis aims to examine if the model fits with the data. The model fit index includes the average path coefficient, average $\mathrm{R}^{2}$, and average variances factor. The criteria of the average path coefficient and average $\mathrm{R}^{2}$ with $\mathrm{p}$-value is below 0.1 while the average variances factor is below 5 .

Table 2: Descriptive Statistics

\begin{tabular}{|l|c|c|}
\hline Variable & Mean & Standard Deviation \\
\hline $\begin{array}{l}\text { Carbon Emission } \\
\text { Disclosure }\end{array}$ & 0.231742 & 0.24239822 \\
\hline $\begin{array}{l}\text { Good Corporate } \\
\text { Governance }\end{array}$ & 19.18992 & 3.2651054 \\
\hline ROE & 0.119642 & 0.27417872 \\
\hline Tobin's Q & 2.028029 & 2.69546891 \\
\hline
\end{tabular}

Table 3: Validity and Reliability

\begin{tabular}{|l|c|c|c|}
\hline Variable & $\begin{array}{c}\text { Loading } \\
\text { Factor }\end{array}$ & $\begin{array}{c}\text { Composite } \\
\text { Reliability }\end{array}$ & $\begin{array}{c}\text { Cronbach's } \\
\text { Alpha }\end{array}$ \\
\hline $\begin{array}{l}\text { Carbon } \\
\text { Emission } \\
\text { Disclosure }\end{array}$ & 1 & 1 & 1 \\
\hline $\begin{array}{l}\text { Good } \\
\text { Corporate } \\
\text { Governance }\end{array}$ & 1 & 1 & 1 \\
\hline ROE & 1 & 1 & 1 \\
\hline Tobin's Q & 1 & 1 & 1 \\
\hline
\end{tabular}


Table 4 shows that average path coefficient is 0.254 with p-value $<0.001$. Average $\mathrm{R}^{2}$ is 0.124 with p-value $<0.001$. The average variances factor is 1.038 with an ideal index of 3.3. The result indicates that the model is fitted with the data.

\subsection{Hypothesis Testing}

Table 5 shows that the path of Carbon Emission Disclosure on Firm Value has a p-value of 0.27 (insignificant). It indicates that $\mathrm{H} 1$ is rejected, where there is no effect of carbon emission disclosure on firm value. Path of Good Corporate Governance on Firm Value has a p-value of 0.15 (insignificant). It indicates that $\mathrm{H} 2$ is rejected, where there is no effect of good corporate governance on firm value. Path of Carbon Emission Disclosure on Firm Value through Financial Performance has a p-value of 0.001 (significant in 0.01). It indicates that $\mathrm{H} 3$ is accepted, where their financial performance mediates the effect of carbon emission disclosure on firm value. Path of Good Corporate Governance on Firm Value through Financial Performance has a p-value of 0.026 (significant in 0.05 ). It indicates that H4 is accepted, where their financial performance mediates the effect of good corporate governance on firm value.

Table 4: Model Fitness Analysis

\begin{tabular}{|l|}
\hline Model fit and quality indices \\
\hline Average path coefficient $(\mathrm{APC})=0.254, \mathrm{P}<0.001$ \\
Average R-squared (ARS) $=0.244, \mathrm{P}<0.001$ \\
Average adjusted R-squared $(\mathrm{AARS})=0.229, \mathrm{P}<0.001$ \\
Average block VIF (AVIF) $=1.038$, acceptable if $<=5$, \\
ideally $<=3.3$ \\
Average full collinearity VIF $(\mathrm{AFVIF})=1.206$, acceptable if \\
$<=5$, ideally $<=3.3$
\end{tabular}

Table 5: Hypothesis Testing

\begin{tabular}{|l|c|c|c|}
\hline Path & Beta & p-Value & R2 \\
\hline $\begin{array}{l}\text { Carbon Emission } \\
\text { Disclosure -> Firm Value }\end{array}$ & 0.05 & 0.27 & 0.37 \\
\hline $\begin{array}{l}\text { Good Corporate } \\
\text { Governance -> Firm Value }\end{array}$ & 0.098 & 0.15 & 0.37 \\
\hline $\begin{array}{l}\text { Carbon Emission } \\
\text { Disclosure -> Financial } \\
\text { Performance -> Firm Value }\end{array}$ & 0.184 & $0.001^{* * *}$ & 0.21 \\
\hline $\begin{array}{l}\text { Good Corporate } \\
\text { Governance -> Financial } \\
\text { Performance -> Firm Value }\end{array}$ & 0.119 & $0.026^{* *}$ & 0.21 \\
\hline
\end{tabular}

Note: ${ }^{* *}$ and ${ }^{* *}$ indicates significant at $1 \%$ and $5 \%$ level of significance based on t-statistics

\subsection{Discussion}

Carbon emission disclosure has no effect on firm value. The result is not consistent with previous findings (e.g., Anggraeni, 2015; Luo \& Tang, 2016; Matsumura et al., 2014; Okpala \& Iredele, 2019; Qiu et al., 2016) that show carbon emission disclosure increase firm value. In Indonesia, carbon emission disclosure is voluntary disclosure, so it is hard to find information about carbon emission in the financial report. Firms are less likely to disclosure carbon emission because it is costly to implement the internal measurement system and process of carbon emission. There is also the cost of a market where an investor might give negative responses to the carbon emission disclosure.

Good corporate governance has no effect on firm value. The result is not consistent with Gwenda and Juniarti (2013), Rizki and Jasmine (2018), and Santoso (2017) who find that good corporate governance has an effect on firm value. In Indonesia, good corporate governance is not fully implemented as a corporate governance principle. In other words, corporate governance implementation is an only formality to fulfill the regulation.

Carbon emission disclosure has an effect on firm value through financial performance. The result is consistent with Ardiyanto and Haryanto (2017) who find that return on equity mediates the effect of corporate social responsibility on firm value. Carbon emission disclosure attracts the customer to buy environmentally friendly products and leads to higher revenue. Higher revenue generates higher profitability. Since higher profitability give motivation for an investor to invests their money, the stock price will be increased. Carbon emission disclosure gives a signal that the firm can increase its performance in the future by doing environmental responsibility.

Good corporate governance has an effect on firm value through financial performance. The result is consistent with Santoso (2017) who finds that financial performance mediates the effect of corporate governance on firm value. Good corporate governance provides effective control and monitoring function to ensure that management can achieve higher financial. Since it is the good news for the investor, the investor gives a positive response and increases the firm value.

\section{Conclusions}

This research aims to examine (1) the effect of carbon emission disclosure on firm value, (2) the effect of good corporate governance on firm value, (3) the mediating role of financial performance between carbon emission disclosure and firm value, and (4) the mediating role of financial performance between good corporate governance and firm 
value. Based on data analysis, carbon emission disclosure and good corporate governance have no direct effect on firm value. On the other hand, financial performance mediates the effect of carbon emission disclosure and good corporate governance on firm value. It shows that higher carbon emission disclosure and good corporate governance are meaningless for the investor if it does not give any financial performance improvement. When carbon emission disclosure can increase revenue, then the firm value will be improved as well. When good corporate governance is effective in monitoring management performance then the firm value will be improved as well. The result confirms the signaling concept where carbon emission disclosure and good corporate governance give a signal of sustainability and positive prospect.

This research implies that firms should implement higher carbon emission disclosure and good corporate governance to increase financial performance and firm value. This research also implies that the regulator to formulate regulation of carbon emission disclosure, so all firms can disclose carbon emission information wider. Since carbon emission disclosure is limited in Indonesia, future research can examine carbon emission disclosure elsewhere, such as ASEAN countries.

\section{References}

Anggraeni, D. Y. (2015). Carbon Emission Disclosure, Environmental Performance, and Firm Value. Jurnal Akuntansi Dan Keuangan Indonesia, 12(2), 188-209. https://doi. org/10.21002/jaki.2015.11

Ardiyanto, T., \& Haryanto. (2017). The Effect of Corporate Social Responsibility Disclosure on Firm Value with Financial Performance as Intervening Variable. Diponegoro Journal of Accounting, 6(4), 337-351.

Arisanti, L. A., \& Daljono. (2014). The Effect of Voluntary Disclosure on Firm Value. Diponegoro Journal of Accounting, $3(3), 1-8$.

Barsky, N. P., Hussein, M. E., \& Jablonsky, S. F. (1999). Shareholder and Stakeholder Value in Corporate Downsizing - The Case of United Technologies Corporation. Accounting, Auditing \& Accountability Journal, 12(5), 583-604. https://doi. org/10.1108/09513579910298480

Deegan, C., \& Gordon, B. (1996). A Study of the Environmental Disclosure Practices of Australian Corporations. Accounting and Business Research, 26(3), 187-199. https://doi.org/10.1080 /00014788.1996.9729510

Deegan, C., Rankin, M., \& Tobin, J. (2002). An Examination of the Corporate Social and Environmental Disclosures of BHP from 1983-1997: A Test of Legitimacy Theory. Accounting, Auditing \& Accountability Journal, 15(3), 312-343. https://doi. org/10.1108/09513570210435861
Elkington, J. (1997). Cannibals with Forks: The Tripple Bottom Line of 21st Century Business. Mankato, MN: Capstone Publishing.

Elkington, J. (2001). The Chrysalis Economy: How Citizen CEOs and Corporations Can Fuse Values and Value Creation. Mankato, MN: Capstone Publishing.

Epstein, M. J., \& Freedman, M. (1994). Social Disclosure and the Individual Investor. Accounting, Auditing \& Accountability Journal, 7(4), 94-109.

Gray, R., Owen, D., \& Adams, C. (1996). Accounting \& Accountability: Changes and Challenges in Corporate Social and Environmental Reporting. Upper Saddle River, NJ: Prentice Hall.

Gwenda, Z., \& Juniarti. (2013). Pengaruh Penerapan Good Corporate Governance (GCG) Pada Variabel Share Ownership, Debt Ratio, dan Sektor Industri Terhadap Nilai Perusahaan. Business Accounting Review, 1(2), 137-150.

Hapsoro, D., \& Ambarwati. (2018). Antecedents And Consequences Of Carbon Emissions' Disclosure: Case Study Of Oil, Gas And Coal Companies In Non-Annex 1 Member Countries. Journal of Indonesian Economy and Business, 33(2), 99. https://doi. org/10.22146/jieb.28756

Irwhantoko, \& Basuki. (2016). Carbon Emission Disclosure: A Study on Indonesian Manufacturing Firms. Jurnal Akuntansi Dan Keuangan, 18(2), 92-104. https://doi.org/10.9744/ jak.18.2.92-104

Istikhoroh, S., \& Suhardiyah, M. (2016). The Role of Corporate Social Responsibility Disclosure in Improving the Effect of Return on Equity on Firm Value. Majalah Ekonomi, XXI(2), 275-285.

Kelvin, C., Daromes, F. E., \& Ng, S. (2017). The Effect of Carbon Emission Disclosure as Performance Improvement Mechanism to Create Firm Value. Dinamika Akuntansi, Keuangan Dan Perbankan, 6(1), 1-18.

Khan, U., Haque, M. I., \& Khan, A. M. (2020). Environmental Sustainability Awareness in the Kingdom of Saudi Arabia. Journal of Asian Finance, Economics and Business, 7(9), 687-695. https://doi.org/10.13106/jafeb.2020.vol7.no9.687

Lako, A. (2018). Green Accounting: Issue, Theory, and Application. Jakarta, Indonesia: Salemba Empat. [Indonesian]

Levin, K., \& Fransen, T. (2017). Understanding the "Emission Gap” in 5 Graphics. WRI Indonesia. https://wri-indonesia. org/id/blog/memahami-“kesenjangan-emisi”-dalam-5-grafik. [Indonesian]

Lindblom, C. K. (2010). The Implications of Organizational Legitimacy for Corporate Social Performance and Disclosure. In: Social and Environmental Accounting (2nd ed.). London, UK: Sage Publications.

Luo, L. Le, \& Tang, Q. (2016). Does National Culture Influence Corporate Carbon Disclosure Propensity? Journal of International Accounting Research, 15(1), 17-47. https://doi. org $/ 10.2308 /$ jiar-51131 
Machmuddah, Z., Sari, D. W., \& Utomo, S. D. (2020). Corporate Social Responsibility, Profitability and Firm Value: Evidence from Indonesia. Journal of Asian Finance, Economics and Business, 7(9), 631-638. https://doi.org/10.13106/jafeb.2020. vol7.no9.631

Magness, V. (2006). Strategic Posture, Financial Performance and Environmental Disclosure. Accounting, Auditing \& Accountability Journal, 19(4), 540-563. https://doi. org/10.1108/09513570610679128

Mathews, M. R. (1993). Social Responsible Accounting. New York, NY: Chapman-Hall Publishers.

Matsumura, E. M., Prakash, R., \& Vera-Muñoz, S. C. (2014). FirmValue Effects of Carbon Emissions and Carbon Disclosures. The Accounting Review, 89(2), 695-724. https://doi.org/10.2308/ accr-50629

Meek, G. K., Roberts, C. B., \& Gray, S. J. (1995). Factors Influencing Voluntary Annual Report Disclosures By U.S., U.K. and Continental European Multinational Corporations. Journal of International Business Studies, 26(3), 555-572. https://doi.org/10.1057/palgrave.jibs.8490186

Mutmainah. (2015). Analysis of Good Corporate Governance on Firm Value. EKSIS, 10(2), 181-195. https://doi.org/10.26533/ eksis.v10i2.63

Nguyen, S. La, Pham, C. D., Nguyen, A. H., \& Dinh, H. T. (2020). Impact of Corporate Social Responsibility Disclosures on Bankruptcy Risk of Vietnamese Firms. Journal of Asian Finance, Economics and Business, 7(5), 81-90. https://doi. org/10.13106/jafeb.2020.vol7.no5.081

O'Donovan, G. (2002). Environmental Disclosures in the Annual Report: Extending the Applicability and Predictive Power of Legitimacy Theory. Accounting, Auditing \& Accountability Journal, 15(3), 344-371. https://doi. org/10.1108/09513570210435870

Okpala, O. P., \& Iredele, O. O. (2019). Corporate Social and Environmental Disclosures and Market Value of Listed Firms in Nigeria. Copernican Journal of Finance \& Accounting, 7(3), 9-28. https://doi.org/10.12775/CJFA.2018.013

Ongsakul, V., \& Sen, S. K. (2019). Low Carbon Energy Symbiosis for Sustainability: Review of Shared Value-based Policy Metabolism to Enhance the Implementability of the Sustainable Development Goals in Asia. International Journal of Energy Economics and Policy, 9(2), 24-30. https://doi.org/https://doi. org/10.32479/ijeep.7236

Patten, D. M. (1991). Exposure, Legitimacy, and Social Disclosure. Journal of Accounting and Public Policy, 10(4), 297-308. https://doi.org/10.1016/0278-4254(91)90003-3

Patten, D. M. (1992). Intra-Industry Environmental Disclosures in Response to the Alaskan Oil Spill: A Note on Legitimacy
Theory. Accounting, Organizations and Society, 17(5), 471-475. https://doi.org/10.1016/0361-3682(92)90042-Q

Prasinta, D. (2012). The Effect of Good Corporate Governance on Financial Performance. Accounting Analysis Journal, 1(2), 1-7. https://doi.org/10.15294/aaj.v1i2.655

Qiu, Y., Shaukat, A., \& Tharyan, R. (2016). Environmental and Social Disclosures: Link with Corporate Financial Performance. The British Accounting Review, 48(1), 102-116. https://doi. org/10.1016/j.bar.2014.10.007

Radhouane, I., Nekhili, M., Nagati, H., \& Paché, G. (2018). The Impact of Corporate Environmental Reporting on CustomerRelated Performance and Market Value. Management Decision, 56(7), 1630-1659. https://doi.org/10.1108/MD-03-2017-0272

Rizki, A., \& Jasmine, A. (2018). Investor Protection, Corporate Governance, Firm Value: Research on the Companies in Asia. KnE Social Sciences, 3(10), 547-565. https://doi.org/10.18502/ kss.v3i10.3403

Saka, C., \& Oshika, T. (2014). Disclosure Effects, Carbon Emissions and Corporate Value. Sustainability Accounting, Management and Policy Journal, 5(1), 22-45. https://doi. org/10.1108/SAMPJ-09-2012-0030

Santoso, A. (2017). The Effect of Good Corporate Governance on Firm Value with Financial Performance as Intervening Variable. Prosiding Seminar Nasional Dan Call For Paper Ekonomi Dan Bisnis, 67-77. [Indonesian]

Siahaan, F. O. P. (2014). The Effect of Good Corporate Governance Mechanism, Leverage, and Firm Size on Firm Value. GSTF Journal on Business Review, 2(4), 137-142. https://doi. org/10.5176/2010-4804_2.4.263

Somjai, S., Fongtanakit, R., \& Laosillapacharoen, K. (2020). Impact of Environmental Commitment, Environmental Management Accounting and Green Innovation on Firm Performance: An Empirical Investigation. International Journal of Energy Economics and Policy, 10(3), 204-210. https://doi.org/10.32479/ijeep.9174

Ulum, I. (2017). Intellectual Capital: Measurement Model, Disclosure Framework \& Organizational Performance. Universitas Muhammadiyah Malang, Indonesia. [Indonesian]

Wardani, R. P. (2011). Determinant Factors of Voluntary Disclosure. Jurnal Akuntansi Dan Keuangan, 14(1), 1-15. https://doi. org/10.9744/jak.14.1.1-15

Wiranata, I. W. E. (2014). Market Reaction on Publication of Environmental Performance Rating. E-Jurnal Akuntansi Universitas Udayana, 8(3), 408-422.

Zulhaimi, H. (2015). The Effect of Green Accounting Implementation on Firm Performance (A Study on Green Industry Firms listed in IDX). Jurnal Riset Akuntansi Dan Keuangan, 3(1), 603. https://doi.org/10.17509/jrak.v3i1.6607 